\title{
Special Problems Of Special Collections
}

BY FRANCES J. BREWER

$\mathrm{T}$ HE LibRARY of Duke Frederigo of Montefeltre, Count of Urbino, (14441482 A.D.) was described by his librarian and biographer Vespasiano ${ }^{1}$ as containing one perfect copy of every known work at that time, sacred or profane, in the original tongue or in translation. The duties of the librarian were clearly stated in a code issued under Guidobaldo I, son of Frederigo: ${ }^{2} \mathrm{He}$ must be not only learned but of pleasing personality ... keeping an inventory of the books and having them so arranged that they can be reached easily. . . . According to Vespasiano, ${ }^{3}$ the collection began with the Latin poets and their commentators, then the orators, historians, philosophers (Roman and Greek, the latter in Latin translation). Next, sacred subjects, astrology, medicine, mathematics, followed by "modern" writers, such as Petrarch, and finally an array of Greek poets. According to Vespasiano, the collection was not contaminated by the presence of even one printed book. However, the last Duke of Urbino (1549-1631) did not share Frederigo's distaste for printed books; he formed a separate library especially for them. An "Index vetus" was discovered, probably preceding Vespasiano's catalog, containing additional lists of books of miscellaneous nature, prefaced by headings such as "Books not bound in parchment," or "Books in the Mother-Tongue," or "Books which were in the other Library." It is difficult to believe that this Renaissance library of about twelve hundred titles may serve as an example in pointing out all problems and aspects of special collections. Each

\footnotetext{
1 Vespasiano de Bisticci, Le Vite di uomini illustri del secolo $x v$, (Florence, 1859).

$3 \mathrm{~J}$. Dennistoun, Memoirs of the Dukes of Urbino, reedited by Edward Hutton. (New York and London, 1909).

3 Op. cit.
}

Mrs. Brewer is Chief, Gifts and Rare Books Division, Detroit Public Library.

subject under which the books were arranged formed a special collection, physically separated from the others bu. accessible by the use of an index or ir ventory. The fact that there was a differ ence in language called for yet another physical separation, again available by use of the one index. Third, there was a form division because of the separate treatment of printed books versus manuscripts, causing yet another separation or division into two special collections.

In 1622 Gabriel Naude librarian to Cardinal Mazarin, published his "Advis" (instructions concerning the erecting of a library). ${ }^{4}$ He wrote:

The point, which seems absolutely necessary to be treated ... is that of the Order and Disposition which books observe in a Library; for without this, doubtless, all inquiring is to no purpose ... They have to be ranged, and disposed according to the variety of their subject . . I I affirm, moreover, that without this Order and disposition, be the collection of books whatever . . . it would no more merit the name of a Library, than an assembly of thirty thousand men the name of an Army ... till they be placed and put together according to rule ... I conceive that to be alwayes the best which is most facil, the least intricate, most natural, practised, and which follows the faculties of Theologia, Physick, Jurisprudence, Mathematicks, $\mathrm{Hu}$ manity. . .

The foregoing examples show that problems connected with the arrangement of books exist wherever books are

4 Gabriel Naude Instructions Concerning Erecting of a Library (Cambridge: printed for Houghton, Mifflin \& Co., 1903). 
assembled to form a library. There are, it seems, three types of special collections:

1. The special author or subject coltion.

2. The special collection arranged by form.

3. The library within a library e.g. Elkins, Widener, Berg, etc., Collection.

The separation of the "form collection" from the main body of the collection is hardly ever questioned by cataloger, librarian, or administrator. If a library acquires or accepts as a gift miniature books, there is little doubt thatbecause of their physical structure-the collection will be kept separate from other holdings. Although there are relatively few libraries which can take pride in substantial manuscript collections, most have at least some isolated manuscripts tucked away in a vault or a locked case. Whether they are autograph letters written by the first president of the university, or by a famous alumnus, or a president of the United States whose letters to his boyhood "hometown girl" have been given to the local library, or whether they consist of one or two stray mediaeval manuscripts which have found their resting place in the small college or public library, a precedent for a special collection has been established. Reference versus circulating books in public libraries, books for the graduate level versus the undergraduate, mean that the holdings are divided into two separate units or special collections.

There is no library-private, institutional, or public-which cannot be looked upon as an accumulation of special collections. Should a private collector decide to concentrate on one author only, his library will consist of the author's works, his contributions to books and periodicals, biography and criticism, manuscript material, and sometimes memorabilia. In a way, then, our interest in one single writer produces a collection of five or more special collections. A subject interest will result in special collections of books dealing with the history, with the subject itself, with material contained in books of broader scope, and, finally, with books dealing with individual segments of the subject. A cookbook collection will include early medicine, herbals, housekeeping books, general cookbooks, and, finally, various phases like candy-making and salads.

A glance at the literature of special collections shows that "contents" are being discussed in many papers. Acquisition and administrative problems connected with the maintenance are seldom the subject of a dissertation. Cecil K. Byrd in an article "Collecting Collections" 5 states rightly that there is no library which does not acquire collections by purchase or gift. We might add that the larger library is much more likely to acquire special collections than the small one. It depends, however, on the administrative policy of an institution whether a collection is kept as a separate unit at any cost, and I mean cost, or is dispersed and distributed among the general holdings of the library. No hard and fast rule, it seems, exists in any library in this respect, because the scope of the acquired collection and its impact on the holdings of a given library will have to be considered, so that an intelligent decision can be made as to which form the collection will be most useful. Any libraryuniversity or public-is naturally divided into special collections by classification. For instance, the books in the 010's of the Dewey decimal classification can be regarded as a special collection.

The larger a library's holdings the greater is the probability that collections will be developed in special fields. In these times, when a library cannot possibly be all-inclusive, it can only aim at satisfying superficially the quest for knowledge in all fields. In addition to

\footnotetext{
${ }^{5}$ Library Trends, IV. (1956) No. 4.
} 
a good coverage of general material, a choice has to be made in the development of one or more disciplines, which can be thoroughly covered for intense and advanced study.

The general card catalog serves to bring together all the material contained in a library, and at the same time has the function to serve as a guide to special collections. If the author or title of a book is known and looked up by the user of the general catalog, its call number discloses its subject as well as its physical location. If a subject is being consulted, cards listed under one subject heading represent a special collection, although the material will not necessarily be found in one single place. Large or small, any collection can be separated physically without lessening its accessibility to any degree as long as the books are cataloged and classified so that their location can be determined by consulting the card catalog.

Subject departments are generally furnished with a catalog containing cards for books in one specific classification, thus covering only one field of knowledge and thereby making it easier to consult the catalog because there are fewer cards to be examined. However, the serious scholar, after exhausting the material in a given department, cannot be satisfied unless he consults the general catalog for fringe materials which may be found in other departments. If interested in the history and geography of some territory, the material in the history department will have to be checked first.

Economic conditions of a country, which are most certainly a contributing factor to its history, will have to be located in the general catalog, which will refer the user to the special collections in the social sciences section. If there is special interest in a person of literary fame, that is, in the works of one particular author, it is essential to locate all material written by this author. With- out doing this, his significance cannot be fully understood. John Galsworthy, for instance, who was interested in the prevention of cruelty to animals, authored a number of pamphlets in which he expressed himself in a completely different technique from his novels. His versatility can only be appreciated by examining the style he used in some of these rather obscure pamphlets. The card catalog is the key to all special collections contained in a library. Imagine our helplessness if we had to consult a catalog containing author and title entries only for one million books. The Dewey or Library of Congress classification schemes, as well as departmentalization, have been accepted without question by library administrators in this country. However, there seems to be a certain reluctance to go beyond the accepted norms and specialize even further, by establishing additional separate classification schemes in one or another limited field.

The question arises whether an institution should aim at the establishment and acquisition of special collections, and whether there should be a minimum quantity of material below which a special collection should never be formed. It is true that books concerned entirely with a given subject, or treating it in part, can be found by consulting the card catalog under the desired heading. Many librarians work with shelf-list cards rather than with subject headings when exploring a given subject. Therefore, classification systems devised expressly for special collections do have disadvantages as far as librarians are concerned.

If a special classification has been adopted for a collection, the catalog cards in the general catalog should bear a location stamp or symbol rather than a call number which does not fit into the general scheme. The Burton collection of the Detroit Public Library, for instance, has its own classification system, based on Dewey and employing capital 
and small letters as symbols for cities and counties. The Dewey number for Michigan is 977.4. The call number for Detroit (in Burton) is 74D4, for Wayne County $74 w 1$. Cities are denoted by capitals and Cuttered by their name, counties by lower case letters and Cutter number. The cards in the general catalog, consisting of a complete set, are stamped "Burton," referring the interested person to that department, where he may consult the departmental catalog.

There is another way to keep a small collection together, without having to adopt a special classification scheme. A checklist of the collection in the acquisitions or any other department can serve as a guide. It is possible to refer the interested person to this checklist by inserting cards under the name and the subject of the collection in the general catalog, e.g. "Smith, Joseph. Cookbook Collection. For a list of the books, see the .. . Department." If some of the material is of miscellaneous nature, including memorabilia, manuscripts, correspondence, etc., a card may indicate the existence of such material, referring the user to detailed lists and catalogs.

Format will determine the shelving of a collection to some extent. Space permitting, it would be ideal to have book and manuscript material included in one collection, in one location. However, space does not usually permit having bookshelves and vertical file material in one place.

Libraries are many times confronted with the gift of a private collection composed largely of books of general nature, but emphasizing in its holdings one or more special categories of particular interest to the original owner. Another type offered is the library of a book collector: a subject collection, an author collection or a collection on any phase connected with the history or art of the book itself. Such collections may consist of books only, books and manuscripts, manuscripts and letters, clip- pings and prints, etc. A general collection, assembled by an individual with varied interests, would hardly get its maximum use by being kept together. Yet, in recent times, we have experienced many instances in which valuable studies depended on the holdings of the original library. Justified work has gone into the assembling of the original Jefferson library. There are universities which try to reconstruct their original libraries. A list of books or a printed cata$\log$ is only a sorry substitute for the feeling conveyed by the actual collection of books shelved in one location. It is true that a list opens avenues to research and study which lead to conclusions on the status and interests of the owner and the books read and collected in his times. The list can also be used in reconstructing the library.

An example taken from my own experience is the story of Father Gabriel Richard's library and its inventory. Father Richard, born in France in 1764, was sent with other Sulpitians to Baltimore in 1792. He accepted the duty of missionary work in Illinois and was transferred to Detroit in 1798, where he performed parochial duties. He was the first to establish a printing press in Detroit. Father Richard assembled a huge library of books brought or purchased from his homeland, in addition to books acquired in America. The library remained and was maintained in the Chancery of Detroit after his death. Fr. Richard inscribed many of his books, and made marginal annotations while reading and studying.

The largest part of the collection was acquired some years ago by the University of Michigan, but some of the books made their way to the Burton historical collection of the Detroit Public Library, some to the Clark historical collection of Central Michigan College in Mount Pleasant, some to the Sacred Heart Semi-

(Continued on page 255) 


\section{Special Collections ...}

(Continued from page 216)

nary in Detroit, and some were discovered-to my great amazement-among an array of other uncataloged gift books of varying value and importance in the relatively new St. John's Seminary in Plymouth, Michigan. Some were even offered for sale in New York a few years ago. It so happened that at the time of Father Richard's death, an almost illiterate person made a list of the good Father's rather shabby belongings that included the books in his library. It seems important to me to see that someone translates this list into bibliographical language so that as many books as possible can be located and re-assembled, if necessary. For early Detroit history and an understanding of Father Richard's life and career, the contents of his library would certainly reveal a good deal of information. Too bad this very special collection was dispersed, but at least there is a scanty list.

We are aware of the fact that some collections were assembled which should be dispersed, although the owner and prospective donor may think otherwise. It is the rigid rule and policy of some libraries not to accept any collection which is being presented with the stipulation of being kept together. It seems, however, that librarians have grown so much accustomed to receiving generous gifts that they are sometimes prone to refuse a perfectly legitimate request of a donor who wants his books kept together. After all, why shouldn't a person have the perfectly natural thought of visualizing in one location his life's most cherished endeavor? Many librarians appear to be so convinced that collections are given to an institution for no other reason but the advantage of income tax deduction that they are likely to overlook the often genuine desire of a person to see his collection in toto preserved in his favorite institution. Certainly, if no special classification scheme has to be devised, and space is available, there is no valid reason for refusing this stipulation. This decision depends, of course, on the importance of the material. When presented with " 50 books of the year 1958," we most certainly are inclined to refuse a request for physical togetherness. Yet, we might be able to persuade the collector to make the gift even though his particular request has to be turned down, by showing him that by using the 1958 list of books published by the American Institute of Graphic Arts, his collection can be assembled at any time without much effort. There is a danger of separating books belonging to a special collection and incorporating them in the general holdings of the library by using the adopted classification. Parts of the collection may be worn out sooner than others. Some material may be used more frequently in connection with research for purposes other than the fact that they are the collection. It is conceivable, for instance, that a library school assignment prescribes studies on English children's magazines. In this case, magazines which belong to a Kate Greenaway collection because they contain some of her illustrations will be used in a completely different context from the one for which they were originally assembled. In this case, precautions can be taken in advance by retaining such magazines in the rare book collection to assure careful use.

In some cases, it is possible to convince the donor that not all of his books warrant being kept together. Part of his collection can be incorporated in the rare book department to form a small but desirable special collection; the rest would be more useful if made easily available to the general public. In recent years, the Detroit Public Library has successfully separated in this manner a cookbook collection of about three thousand volumes, retaining about three hundred in the rare book department, and a history of children's literature col- 
lection which was divided and shared by the rare book and language and literature departments.

One more important aspect of the administration is the publicizing of special collections, not only the ones contained in our own institutions, but especially collections which are found in unlikely places. Personally, I know of ten or more such collections. The Detroit Institute of Arts houses, for instance, part of the Whitney-Hoff collection of fine bindings, and one of the finest collections of books on puppetry, formerly collected and owned by the well-known book designer Paul McPharlin. In the Toledo (Ohio) Art Museum is one of only two collections in the United States devoted to a "Museum of the Book." In a relatively small public library in Saginaw, Michigan, I recently saw an exhibit of a substantial collection of miniature books. Many historical museums and societies have book and manuscript materials which have not been recorded or described in library literature.

Some few tools available for locating special collections are the now somewhat outdated Special Library Resources (1941), Lee Ash's Subject Collections, American Literary Manuscripts, published recently by the Modern Language Association, and DeRicci's Census, with the forthcoming supplement. These are by no means all-inclusive, and it does seem that all of us should assume the responsibility of reporting to proper places all significant special collections which come to our attention. One source of information which may be overlooked by some is the subject listing of specialized dealers in the AB Bookman's Yearbook. When trying to locate special collections for research purposes, specialized book dealers are always most helpful.

Librarians are often surprised when patrons and scholars take it for granted that some special collection should be available in their institution. All of us should make a genuine attempt to form special collections. Unıversities are expected to have collections on their alumni and the history of the institution. The Detroit Public Library, located in the center of the automotive industry, is expected to have an automotive history collection; it has one of the best. Local history collections are expected in even the smallest public library, and so are biographical data of important citizens, and works of local authors.

It is my opinion that special classification schemes are not necessary. Physical separation of collections is often useful, sometimes unavoidable. Checklists or catalogs of special collections are always an asset, especially when the collection must be dispersed and incorporated in the general holdings. There is no library which can escape the acquisition of special collections and the problems connected with their administration.

\section{OTTO HARRASSOWITZ}

\section{Library Agency WIESBADEN - GERMANY}

\author{
Direct service \\ on all German language \\ books and periodicals \\ *
}

Orders and inquiries are invited on both new and out-of-print material

Farmington Plan agent for West and East Germany

$*$

For economy, speed, and accuracy you may rely upon your

German agent

OTTO HARRASSOWITZ 